\title{
What are the Impact of Foreign Aid to the Economic Growth? Time Series Analysis with New Evidence from Tanzania
}

\section{Albiman $\mathbf{M M}^{*}$}

Department of Economics and Management Sciences (FEMS), Universiti Sultan Zainal Abidin, Kuala Terenganu, Terenganu Malaysia, Malaysia

\begin{abstract}
Despite the fact that, Tanzania is receiving large inflows of foreign aid since 1970s to support its economic activities. Yet, very few literatures investigated the impact of foreign aid to economic growth of Tanzania. After revealing that, despite the large inflows of foreign aid in Tanzania, the economic growth rate is apparently low, poverty level and budget deficits is still persisting over the economy. Thus our study intends to further investigate the impact of foreign aid to economic growth by using Dynamic Ordinary Least Square (DOLS). After using endogenous growth model and time series data from 1976-2014, we found that, foreign aid has negative impact to the economic growth. Furthermore, in short run we also found that, foreign aid does not Granger Cause economic growth. The results suggest that, the government has to reconsider the type of foreign aid that is received.
\end{abstract}

Keywords: Foreign aid; Economic growth; DOLS; Tanzania

\section{Introduction}

Since the poor economic performance experienced in late 1970s to mid-1990s, there was a major policy changes in Tanzania as well as African countries. Several strategies were adopted to stimulate privates sectors and open economy policies in general. The promotion of trade sectors, FDI and domestic investment needed financials support from the donors. Thus it was turning point of massive foreign aid inflows from foreign donors to Tanzania and African countries as well.

Several economic programs have been initiated by foreign donors and multilateral aid agencies to ensure that, Tanzania as well as African countries are progressing economically. These initiatives are intended to alleviate the countries from poverty, budget deficits and helping them achieve macroeconomic stability. World Bank in various reports of Sub Saharan African economies from early 1980s up to 2000s has emphasized the increase in foreign aid as an important tool in remediating poverty and ensuring economic prosperity in African countries.

Tanzania as one of Sub Saharan African Country is heavily dependent on foreign aid for long time since 1970s. For example Over 1 billion US \$ is received annually to offset a severe balance of payment deficit [1]. It is argued that, Tanzania is one among the top ten ODA recipients in terms of USD millions. For example, net disbursement in 2008 was 2331 million which is equal to 5 percent debts [1]. Furthermore, for the case of Sub Saharan Africa, Tanzania is one of the largest recipients of aid. For example in financial years 2010-2011 it is approximately $33 \%$ of government spending was financed by foreign aid [1].

Recently since 2000s several strategies have been formed to alleviate the problem of poverty in Tanzania, such as Mkakati wa Kuzuia na Kupunguza Umasikini Tanzania (MKUKUTA) and Mkakati wa kupunguza Umasikini Zanzibar. MKUZA II. Several Development Partners such as Development Partners group (DPGs) has been emerged to ensure that foreign aid can effectively promote economic growth. For example, since formally establishment of DPGs in 2004, it has been working with the government of Tanzania and other domestic stakeholders to strengthen development partnership and effectiveness of development cooperation. DPGs Comprises 17 bilateral and 5 multilateral development agencies.

However, despite the fact that several bilateral and multilateral aid donors to increase foreign aid in Tanzania, the economic growth rate of these countries is apparently low compared to other developing countries. Poor level of technology, low income per capita and poverty levels still persist in Tanzania. According to the World Bank (2006) these countries are still categorized as heavily indebted poor countries (HIPC). This situation raises doubts whether foreign aid inflows in these countries are effective in stimulating economic growth and improving the standard of living. Furthermore, the millennium development goals (MDGs) indicated that, developed countries should increase foreign aid to at least $0.7 \%$ of their GNP. However, despite large inflows of foreign aid in Tanzania throughout two decades, unfortunately Tanzania is still in severe poverty levels and has not shown impressive economic development.

With that linkage, several authors have shown the serious doubts over the foreign aid assistance. For example, Malik [2] suggested that for 30 years foreign aid has not shown any improvement in the standard of living for the developing countries. Moreover, Njoupougnigni and Ndambendia [3] suggested that, the economic and social program has been ineffective in Sub Saharan countries. Furthermore, the rise of debates for the relationship between foreign aid and the economic growth has called upon the need for this study. In fact, according to the endogenous growth theory foreign aid has a long run relationship in sustaining economic growth. However, most of the previous studies had mixed results and unsatisfactory conclusion.

In fact, one of the Millennium Development goals (MDGs), is to eradicate the widening spread of poverty and supporting the economic development in least developed countries (LDCs) such as Tanzania. From this fact, this study intends to examine the long run and short run impact of foreign aid to the economic growth and FDI in Eastern region of Africa. The criteria for selecting the EAC members to be the subject of the study are as follow:

*Corresponding author: Albiman MM, Department of Economics and Management Sciences (FEMS), Universiti Sultan Zainal Abidin, Kuala Terenganu, Terenganu Malaysia, Malaysia, Tel: 6096275546; E-mail: albimani1966@hotmail.com

Received March 15, 2016; Accepted March 30, 2016; Published April 06, 2016

Citation: Albiman MM (2016) What are the Impact of Foreign Aid to the Economic Growth? Time Series Analysis with New Evidence from Tanzania. Bus Eco J 7 : 237. doi:10.4172/2151-6219.1000237

Copyright: (c) 2016 Albiman MM. This is an open-access article distributed under the terms of the Creative Commons Attribution License, which permits unrestricted use, distribution, and reproduction in any medium, provided the original author and source are credited. 
Recently, Tanzania is among the EAC members that formed customs union, common market and economic community. Furthermore, Tanzania is one among sample of the Millennium Development Goals (MDGs) targets, since they are considered as poorest countries in LDCs by the World Banks. The countries receive higher aid in the sense that would help to reduce levels of poverty, budget deficits and improve the socio economic wellbeing by 2015 .

In that sense, the appropriate economic policies are highly needed to ensure that, these countries have appropriate policies to develop themselves from economic backwardness. Thus it is worthwhile to investigate the impact of foreign aid, whether it can reduce the problem of severe poverty and economic development.

\section{Theoretical Literatures}

\section{Foreign aid and economic growth}

The effectiveness of foreign aid in developing countries has been a topic of discussion since the 1960's. The first study was developed by Harrod and domar in 1930s and 1940s. They stressed that foreign aid can increase physical capital accumulation as results economic growth. Harrod Domar model concluded that, foreign aid filling the saving gap in developing countries [4,5].

To strengthen theory of Harrod and Domar model, Chenery and Strout [5], suggested "Two gaps". They suggested that, apart from saving gap, there are foreign exchange gap that hinder the developing countries to import capital goods. Thus they argued that, foreign aid provides funds to the developing countries for the importations of capital goods. Furthermore, Chenery and Strout [5] added the third gap model. The model argued that, there is scarcity of technological advancement, and managerial skills that can be used efficient production. Thus they call human capital gap.

Finally, Bacha [6] Taylor [7] they stressed the concept of "three gap model" by arguing that there is "fiscal deficit" gap. This implies that there is lack of efficient source of revenue to support the economic activities.

\section{Emperical literatures}

Griffin [8] and Griffin and Enos [9] suggested that foreign aid distorts domestic saving. By using the Harold model of economic growth, they showed that, the increase of foreign aid discourage domestic saving in the public sector as results discouraging the government effort in raising the domestic tax base and revenues. They argued that, foreign donors provide aid according to their political desire in developing countries. From this point thus, foreign aid cannot guarantee economic growth in developing countries.

In the late 1990s several literatures suggested that, macroeconomic policies has several importance to ensure that, foreign aid support the economic growth. They argued that, if the countries do not have 'state interventions or "sound macro policies" foreign aid would have a negative impact to the host countries [10-13].

Nyoni [13] suggested that, foreign aid results to appreciate the real exchange rate level in Tanzania. Thus, the increase in foreign aid will increase the price of the domestic products (Dutch disease) ${ }^{1}$ as results will crowd out domestic investment. Thus the government has to

${ }^{1}$ Dutch disease implies the situation where utilization of natural resources within a country or increase in foreign aid lead to the appreciation of the domestic currency which results in the decline of manufacturing sectors due to the expensive price of their domestic products. implement proper policies that will ensure that foreign aid is directed to more productive sectors. This will result to appreciate domestic currency and result in positive economic growth.

On the other hand, Burnside and Dollar [12] in a panel cross section study revealed that, foreign aid can play a positive or negative impact to economic growth in the country depending on macroeconomic policies. However, Easterly et al. [14] expanded sample data for 19701997 from the study of Burnside and Dollar [12], argued that no empirical evidence to support the results of Burnside and Dollar.

Das and Choudhary [15] used both time series methods and panel co integration. They have reported that that there is long run positive relationship between foreign aid and per capita income in Nepal, Sri Lanka, Bangladesh and Pakistan. Furthermore, Njoupognigni and Ndambendia [3] after using dynamic panel analysis found that for 36 sub Saharan African countries foreign aid and FDI have a positive impact to the economic growth. Furthermore, Sakyi [16] supported the results of Das and Choudhary [15], after ARDL test suggested that foreign aid and trade openness have positive impact to the economic growth. On the other hand, Bjerg, et al. [17] suggested that without external debt services, foreign aid does not have a direct positive impact to economic growth. In contrast, Kargbo [18] found that, the impact of foreign aid depends on political stability in the host country.

Generally, there are no conclusive results from the empirical literatures on the relationship between foreign aid and economic growth. The major reasons for this difference perhaps are due to the difference in methods that have been used in making the analysis, difference in measurement, sample size, area of the research and data span.

Specifically, for the case of foreign aid some studies founds that, foreign aid has a direct and positive impact on the economic growth. However, some studies empirically proved that, good economic environment is main prerequisites to ensure the positive impact of foreign aid to the economic growth. Furthermore, several studies have shown that, foreign aid has negative impact on the economic growth.

Major weakness from the previous literatures of 1970s to 1980 analyzed the relationship between foreign aid and economic growth in the Harrod-domar and the Two gap theories. Furthermore, most of the previous literatures were used cross section or panel data methods. Thus in contrast with the previous literatures, our study intends to further investigate the impact of foreign aid to the Tanzania. For the best of our knowledge we have not found the literatures that investigated the impact of foreign aid to the economic growth using time series analysis.

\section{Methodology}

From the study of Nelson and Plosser [19] showed that in macroeconomic variable data there is a problem of a unit root. Thus we use the standard unit root test of Augmented Dickey Fueller Test (ADF) and Philips and Perron test (PP) to test whether our data are stationary or not. For the economic growth model, the study used independent variables such as FDI (LFDI), foreign aid (LAID), export of goods and services (LEXP), labor force (LPOP) and Human capital stock (LH). The following is an illustration of our model specifications:

We derive the endogenous growth theory from the neo classical theory of economic growth developed by Solow [20,21]. This model derived from a Cobb Douglas production function in only two factors of production was considered 


$$
Y=A K^{\alpha} L^{(1-\alpha)}
$$

Where by $\mathrm{K}$ and $\mathrm{L}$ refers to capital stock and labor force respectively, A implies factor productivity which facilitates private capital stock and labor force to stimulate economic growth rate. From the endogenous growth model, value of A implies factor productivity including technology and other foreign capital inflows such as foreign aid and FDI. However, during 1980s, Romer [22] and Lucas [23] argued that there are more factors that can assure sustained economic growth in long $r$ run. These factors include human capital, FDI and trade openness. Thus we derive the endogenous growth model from Cobb Douglas production function

$$
Y=\left[(A H)^{1-\alpha}, K^{\alpha}\right]
$$

A refers to factor productivity, $\mathrm{H}$ refers to human capital stock and $\mathrm{K}$ refers to capital stock or domestic investment. Furthermore, a refers to elasticity of labor or capital to the economic growth.

If we expand the equation (2) now we derive the following equations:

$$
Y=\left(A_{i t} K_{i t}^{\alpha} L^{\beta}{ }_{i t}\right)
$$

Where $\alpha$ and $\beta$ refers to the returns (elasticity) of output with respect to capital and labor force. The value of elasticity is assumed as less than such that: $\alpha$ and $\beta<1$. A refers to externality generated by human capital, FDI and foreign aid inflows which improve efficiency in factors of production. Since the time series data of capital stock $(K)$ is very few thus, we ignore Capital stock (K). Instead, we use only human capital stock $(\mathrm{H})$ and labor force $(\mathrm{L})$ However, unlike most of previous ones that used only raw labor, our model introduced human capital to ascertain its impact on growth. This is considered because in most cases Foreign aid and FDI requires high-level manpower to work with in host country [22].

Therefore since we assume the value $\mathrm{A}=(\mathrm{FDI}$, foreign aid and export) thus we expand the equation (3) which results to the following equation

$$
Y_{i t}=H^{\alpha}{ }_{i t}{ }^{\beta}{ }_{i t} F D I_{i t} F A I D_{i t} E X P_{i t}
$$

Since Y represented by $\log$ of GDP per capital then we take logarithms and factor out derivatives of the equation (4). Thus we generate the following dynamic production function:

$$
L G D P_{t}=\alpha+\beta_{1} L F D I_{t}+\beta_{2} L A I D_{t}+\beta_{3} L E X P_{t}+\beta_{4} L P O P_{t}+\beta_{5} L H_{t}+\varepsilon_{t} .
$$

LGDP refers to economic growth, LAID refers to log of foreign aid, LFDI refers to log of FDI inflows, LEXP refers to log of the labor force refers to labor force and LH refers to log of human capital stock capital stock $\beta_{1} \beta_{2} \beta_{3} \beta_{4}$ and $\beta_{5}$ are the estimated coefficients of relevant variables respectively.

From the specification of the economic growth model we derive the following equation for DOLS.

$$
L G D P=X_{t} B^{\prime}+\sum_{i=-m}^{i=m} \beta \Delta L F D I_{t-i}+\sum_{i=-p}^{i=p} \phi \Delta L A D_{t-i}+\sum_{i=-n}^{i=n} \delta \Delta L E X P_{t-i}+\sum_{i=-k}^{i=k} \gamma \Delta L P O P_{t-i}+\sum_{i=-z}^{i=z} \lambda \Delta H M_{t-z}+\varepsilon_{t}
$$

Where by $\mathrm{X}=\left(1, \mathrm{LFDI}_{\mathrm{t}}, \mathrm{LAID}_{\mathrm{t}}\right.$, LEXP $_{\mathrm{t},}$ LPOP $_{\mathrm{t},}$ LDI $\left._{\mathrm{t}}\right)$ and $\mathrm{B}^{\prime}=$ $(C, \alpha, \beta)$ 'and therefore, $\mathrm{X}_{t} \mathrm{~B}^{\prime}$ implies level form of all variables in Growth models (which are not in difference form). On the other hand, all variables which contain $\Delta$ implies that, they are in first differences form with $\mathrm{t}$ (lead (+) and lag(-). The use of DOLS is hold even if, left hand side variables either LGDP or LFDI are I(1) and at least some of the variables in left side are I(1) or I(0). We did not used Johansen and Juselius method to estimate long run coefficients, because when there is more than one co integrating vectors it is hard to specify one equation of long run coefficient.

The study uses the appropriate methods developed by Stock and Watson [24] which is dynamic ordinary least squares (DOLS). This method favored compared to Static OLS and Johansen and Juselius approach due to the following reasons. Firstly, it is more robust and appropriate for small sample size [25-27]. Secondly, the method is more appropriate in case there endogenous relationship among the variables as in our case. On top of that, it is more appropriate in the case, there will be any serial correlations even of higher order (i.e. more than 1) [25-27]. It is appropriate, even for the variables co integrated or integrated at different order i.e. me (0) and me (1) [25-27].

Since we are also interested to find the short run relationship between foreign aid and economic growth we use Vector error Correction Model in the following model framework.

$$
\begin{aligned}
& I n G D P C_{t}=\alpha_{0}+\sum_{i=1}^{m} \alpha_{1 i} \operatorname{InGDPC}_{t-i}+\sum_{i=1}^{n} \alpha_{2 i} \operatorname{InFDI}_{t-i}+\sum_{i=1}^{n} \alpha_{3 i} \operatorname{InAID}_{t-i} \\
& +\sum_{i=1}^{n} \alpha_{4 i} I n E X P_{t-i}+\sum_{i=1}^{n} \alpha_{5 i} I n D I_{t-i}+\alpha_{6} E C M_{t-i}+\mu_{1 t} \\
& \operatorname{InFDI}_{t}=\phi_{0}+\sum_{i=1}^{m} \phi_{1 i} \operatorname{InFDI}_{t-i}+\sum_{i=1}^{n} \phi_{2 i} \operatorname{InAID}_{t-i}+\sum_{i=1}^{n} \phi_{3 i} \operatorname{InGDPC}_{t-i}+ \\
& \sum_{i=1}^{n} \phi_{4} I n E X P_{t-i}+\sum_{i=1}^{n} \phi_{5 i} I n D I_{t-i}+\phi_{6} E C M_{t-1}+\mu_{2 t} \text {. } \\
& \operatorname{InAID~}_{t}=\delta_{0}+\sum_{i=1}^{m} \delta_{1 i} \operatorname{InAID}_{t-i}+\sum_{i=1}^{n} \delta_{2 i} \operatorname{InGDPC}_{t-i}+\sum_{i=1}^{n} \delta_{3 i} \operatorname{InFDI}_{t-i}+ \\
& \sum_{i=1}^{n} \delta_{4 i} I n E X P_{t-i}+\sum_{i=1}^{n} \delta_{5 i} I n D I_{t-i}+\phi_{6} E C M_{t-i}+\mu_{3 t} . \\
& \operatorname{InEXP_{t}}=\lambda_{0}+\sum_{i=1}^{m} \lambda_{1 i} \operatorname{InEXP}_{t-i}+\sum_{i=1}^{n} \lambda_{2 i} \operatorname{InGDPC}_{t-1}+\sum_{i=1}^{n} \lambda_{3 i} \operatorname{InAID}_{t-i}+ \\
& \sum_{i=1}^{n} \lambda_{4 i} \operatorname{InEXP}_{t-i}+\sum_{i=1}^{n} \lambda_{5 i} \operatorname{InDI}_{t-i}+\lambda_{6} E C M_{t-i}+\mu_{4 t} . \\
& \operatorname{InZ} Z_{t}=\beta_{o}+\sum_{i=1}^{m} \beta_{1 i} \operatorname{InZ}_{t-i}+\sum_{i=1}^{n} \beta_{2 i} \operatorname{InGDPC}_{t-1}+\sum_{i=1}^{n} \beta_{3 i} \operatorname{InAID}_{t-i}+ \\
& \sum_{i=1}^{n} \beta_{4 i} I_{n F D I_{t-i}}+\sum_{i=1}^{n} \beta_{5 i} I n E X P_{t-i}+\beta_{6} E C M_{t-i}+\mu_{5 t} .
\end{aligned}
$$

$\Delta$ Denotes the changes in variable or first differences, $\operatorname{In} R Y$ denotes the value of value of economic growth at given country, $\operatorname{In} Z_{t-1}$ represent control variables such as human capital, labor force, capital formations which implies domestic investment. This is included as control variables. InFDI denotes the value of foreign direct investment (FDI), InEXP, denotes the value of exports at given country, InODA denotes the value of foreign aid inflows at given country, $a$ denotes the constant term and $\mu$ denotes the error terms value for equation 9 up to equation 13 .

\section{Descriptions of data and sources}

This study used annual data with the spanning from 1970 until 2010. The data and time period collected is as follows, Kenya (19702010), Uganda (1970-2010), Burundi (1970-2006), Rwanda (1976- 
Citation: Albiman MM (2016) What are the Impact of Foreign Aid to the Economic Growth? Time Series Analysis with New Evidence from Tanzania. Bus Eco J 7: 237. doi:10.4172/2151-6219.1000237

Page 4 of 7

2010). The data collected from UNCTAD online database key indicators and World's Bank indicators (WDI). Table 1 provides the descriptions of the variables and data source.

\section{Analysis and Discussion}

After considering all the three tests, with and without intercept, it is concluded that, all variables are not stationary in level form Table 2. Furthermore, the results of unit root suggesting that all variables are stationary after first differencing.

Even if, one argues that, variables are integrated in different order, we can still continue to test for co integration or estimate long run using Dynamic Least Square methods (DOLS). Dynamic Ordinary Least Square (DOLS) allows estimating the long run estimation, even if variables are in different order forms [24,26,27] (Tables 2 and 3).
On other hand, from Table 4, the results of co integration indicate that, max Eigen test indicate that there is one co integration relationship among the variables. However, for the case of Trace test, indicate that there are 4 co integrating equations that tied all variables together in the long run. This implies that LFDI, LEXP, LAID, LHM, LDI, and LPOP has long run impact to the GDP per capita in Tanzania. All variables are important in affecting the economic growth. Any poor policies to one among these variables would have long run effect to the economic growth of Tanzania (Table 4).

In general, if variables are co integrated implies two main points. Firstly, Engle and Granger concluded that when the variables are co integrated there should be at least any type of causality relationship. However, Masih and Masih [28,29] argued that, even if co integration can detect the presence or absence of granger causality, cannot show the clear direction of causality between variables. Direction of Causality

\begin{tabular}{|c|c|c|c|}
\hline Variable & Measurement & Descriptions & Sources \\
\hline Economic growth & GDP per capita & $\begin{array}{l}\text { Real GDP which includes domestic productions, expressed in US \$ } \\
\text { millions, expressed in real value }\end{array}$ & UNCTAD, World Bank \\
\hline FDI & FDI-GDP ratio & $\begin{array}{l}\text { Value of foreign direct inflows expressed in US \$ millions at current } \\
\text { price }\end{array}$ & UNCTAD, World Bank \\
\hline Export & Export-GDP ratio & $\begin{array}{l}\text { Value of export of goods and services expressed in US \$ millions } \\
\text { expressed in current prices }\end{array}$ & UNCTAD, World Bank \\
\hline Domestic investment & Capital formation-GDP ratio & $\begin{array}{l}\text { Total outlays or additions of fixed assets in the economy plus net } \\
\text { changes in inventories excludes all forms of FDI, it expressed in US } \\
\$ \text { millions, expressed at current price }\end{array}$ & World Bank \\
\hline Foreign aid & Net ODA-GDP ratio & $\begin{array}{l}\text { The value of disbursement of loans and Grants for development } \\
\text { activities, expressed in US \$ millions at current prices }\end{array}$ & UNCTAD, World Bank \\
\hline Labor force & Active population & $\begin{array}{l}\text { Active population expressed in terms of number of active working } \\
\text { population of } 15 \text { years and above }\end{array}$ & World Bank \\
\hline
\end{tabular}

Table 1: Description of data and sources.

\begin{tabular}{|l|c|c|c|c|}
\hline Variables & C & \multicolumn{1}{c|}{ C and T } & \multicolumn{2}{c|}{ C and T } \\
\hline ADF & \multicolumn{2}{|c|}{ PP TEST } \\
\hline InGDPC & $4.730075(8)$ & $-0.408105(8)$ & $-1.102814(2)$ \\
\hline InFDIGDP & $-7.659607(8)^{*}$ & $-2.136497(8)$ & $-861616(3)$ \\
\hline InAIDGDP & $-2.234551(0)$ & $-2.036225(0)$ & $-2.251154(2)$ \\
\hline InEXPGDP & $-0.644054(0)$ & $-2.876972(7)$ & $-2.255188(1)$ & $-0.837300(1)$ \\
\hline LHM & $1.640310(0)$ & $0.515308(0)$ & $-2.070325(1)$ & $-2.821611(2)$ \\
\hline LPOP & $-1.247738(4)$ & $-3.296036(3)$ & $-160805(3)$ \\
\hline
\end{tabular}

Table 2: Results of unit root in level form.

\begin{tabular}{|l|c|c|c|}
\hline Variables & C & C and T & C \\
\hline Tanzania & & & \\
\hline InGDPC & -0.811306 & $-7.191623(7)$ & $-2.398267(4)$ \\
\hline InFDIGDP & $-1.262513(8)$ & $-6.668542(7)$ & $-12.52627(4)$ \\
\hline InAIDGDP & $-5.784317(0)$ & 0 & $-5.784953(2)$ \\
\hline InEXPGDP & $-1.911666(7)$ & $-2.869144(5)$ & $-4.041037(2)$ \\
\hline LHM & 0 & 0 & $-12.40503(4)$ \\
\hline LPOP & $-1.722697(3)$ & 0 & -18.75634 \\
\hline
\end{tabular}

Table 3: Results of unit root after first difference.

\begin{tabular}{|c|c|c|c|}
\hline B.TANZANIA (1) & Maximum Eigen value & 95\% critical value & Trace test \\
\hline$r=0$ & 103.1959 & 40.07757 & 193.2869 \\
\hline$r \leq 1$ & 31.69821 & 33.87687 & 90.09098 \\
\hline$r \leq 2$ & 27.54956 & 27.58434 & 58.39278 \\
\hline$r \leq 4$ & 17.24917 & 21.13162 & 30.84322 \\
\hline$r \leq 5$ & 10.14534 & 14.26460 & 47.85613 \\
\hline
\end{tabular}

Table 4: Results of Johansen and juselius multivariate co integration test. 
can only be shown by the Vector correction model (VECM). Secondly, VAR in the first difference cannot longer be used because there would be the mis specification. The main reason for this mis specification is that, it cannot include the residuals of lagged period.

The lag length will be selected using information criteria of AIC and Schwarz criteria. These are common test used to determine lag lengths as we have discussed earlier in the lag selection criteria. Given that there are six variables in the system, there can be at most 5 co integrating vectors in the system. The whole test will be done using EVIEWS 7 software. These all results will be presented in Table 5 .

After having found that variables have long run equilibrium relationship for all countries, it is our task now to estimate the long run coefficients. Following the weakness of standard OLS approach and JJ test we present their results and compare with the DOLS. Method of DOLS it can cover problem of endogeneity and serial correlation that is not covered in SOLS. It can be used even for small sample compare to JJ test and SOLS. From this fact, we present the results of all two methods DOLS and SOLS. However, our main focus is for DOLS as we can see in the table, standard error and adjusted $\mathrm{R} \wedge 2$ for DOLS favored compare to SOLS (Table 5).

The results from Table 5, DOLS show that, foreign aid; export, human capital and labor force (proxied by population) was only significant factors that affecting the GDP per capital. Human capital has highest impact $(1.7 \%)$ followed by labor force (1.11\%), export $(0.26 \%)$ and least one is foreign aid $(-0.12 \%)$. In general, export has positive and significant impact to GDP per capital, while foreign aid found to have negative impact to GDP per capital. This implies that export is more important to the economic growth of Tanzania, compare to FDI and foreign aid flows. For the standard ordinary least squares (SOLS) all variables had expected positive sign, but all variables were not significant except for Human capital at five percent level of significance.

Since our study concentrate on foreign aid, we found that, in long run foreign aid has negative impact to the economic growth. These results are also supported by the previous empirical and theoretical literatures such as $[2,8,9,11,12,30]$. The negative impact of foreign aid to economic growth has several implications. The increase in foreign aid can distorts domestic saving, increase domestic consumptions and discourages tax revenue in these countries. Furthermore, foreign aid is given according to the political needs and not economic needs. This creates major economic problems and results to support unproductive projects which results to negative impact to economic growth. Furthermore, according to Burnside and Dollar [12] revealed that for poor economic policies countries, foreign aid expected to have negative impact to economic growth.

Furthermore, for the short run (Causality) that was shown by Vector Error Correction Model (VECM). Only two error correction terms of FDI and populations (labor force) responds to any deviations from equilibrium relationship. Other variables included in the model such as foreign aid, economic growth, export and human capital, population's growth does no responds to any short run deviations from equilibrium. The significance of two error correction term proves our results of co integration we have got earlier. For the short run period results are illustrated in (Table 6 and Figure 1).

The main result here is that, foreign aid granger causes FDI inflows in short run and not otherwise at ten percent level of significance. Unfortunately, this impact is not transmitted to economic growth which implies major policy problems. For other variables we found that, export granger cause GDP per capital and vice versa. The increase in GDP per capital granger causes FDI inflows and not vice versa. Furthermore, export has indirectly impact to FDI through stimulating higher economic growth. On top of that, export directly granger cause FDI inflows and not vice versa.

In general, for the short run period, we found that, foreign aid has not any impact to economic growth in Tanzania. Perhaps due to poor economic policies in these countries foreign aid inflows do not have impact to economic growth [12].

\section{Conclusion and Recommendations}

Since the poor economic performance experienced in late 1970 s to mid 1990s, there was a major policy changes in Tanzania as well as African countries. Several economic programs have been initiated by

\begin{tabular}{|c|c|c|c|c|c|c|}
\hline \multicolumn{7}{|l|}{ Tanzania } \\
\hline Estimates & Constant & LFDI & LAID & LEXP & LHM & LPOP \\
\hline SOLS & $\begin{array}{c}-19.99889 \\
(-24.76888)\end{array}$ & $\begin{array}{c}0.010623 \\
(1.473687)\end{array}$ & $\begin{array}{l}-0.067558^{*} \\
(-3.076153)\end{array}$ & $\begin{array}{l}0.162581^{*} \\
(0.027852)\end{array}$ & $\begin{array}{c}2.347334 \\
(8.459008)\end{array}$ & $\begin{array}{c}1.03727^{*} \\
(20.59029)\end{array}$ \\
\hline \multicolumn{7}{|c|}{ R square adjusted $0.99=$ Normality $\mathrm{JB}=()$, Ramsey test ()$, \mathrm{F}$ statistics $=765.37$} \\
\hline DOLS [1] & $\begin{array}{c}-20.35754 \\
(-56.61159)\end{array}$ & $\begin{array}{c}-0.004048 \\
(-0.548930)\end{array}$ & $\begin{array}{l}-0.121207^{*} \\
(-4.278133)\end{array}$ & $\begin{array}{l}0.264000^{*} \\
(13.24722)\end{array}$ & $\begin{array}{l}1.782220^{*} \\
(4.485608)\end{array}$ & $\begin{array}{l}1.1116788^{*} \\
(15.08899)\end{array}$ \\
\hline
\end{tabular}

$\mathrm{R}$ adjusted 0.99 , sum of squared residuals $=(0.00)$. Notes * and ${ }^{* *}$ are significant at 5 and 10 percent level respectively.

Table 5: Results of Dynamic Ordinary Least Square (DOLS) and Standard Ordinary Least Square (SOLS).

\begin{tabular}{|c|c|c|c|c|c|c|c|}
\hline \multirow[t]{2}{*}{ Dependent variables } & \multicolumn{6}{|c|}{ Independent variables $X^{2}$ statistics of lagged first differenced term ( $p$ values) } & \multirow{2}{*}{$\begin{array}{c}\mathrm{ECT}_{t-1} \\
\text { [t-ratio] }\end{array}$} \\
\hline & $\Delta$ LGDP & $\Delta$ RFDI & $\triangle R E X P$ & $\Delta$ RAID & $\Delta$ LPOP & $\Delta \mathrm{LH}$ & \\
\hline$\triangle \mathrm{LGDP}$ & - & $0.10(0.61)$ & $3.02 *(0.01)$ & $0.02(0.87)$ & $4.22 *(0.02)$ & $4.06 *(0.04)$ & $-0.22^{*}[2.79]$ \\
\hline$\Delta$ LFDI & $7.48^{*}(0.02)$ & - & $0.79(0.3)$ & $0.07(0.7)$ & $3.34^{*}(0.03)$ & $0.24(0.61)$ & $2.36^{*}[3.18]$ \\
\hline$\triangle$ LEXP & $7.54^{*}(0.00)$ & $0.10(0.74)$ & - & $0.13(0.7)$ & $0.47(0.49)$ & $2.31^{*}(0.01)$ & $-0.40[-1.0]$ \\
\hline$\Delta$ LAID & $6.13(0.01)$ & $0.22(0.63)$ & $1.46(0.2)$ & - & $0.36(0.54)$ & $7.48^{*}(0.00)$ & $-4.01[-0.6]$ \\
\hline$\triangle \mathrm{LPOP}$ & $3.23^{*}(0.03)$ & $0.82(0.36)$ & $4.02 *(0.02)$ & $6.53^{*}(0.04)$ & - & $3.68^{*}(0.01)$ & $0.32[1.13]$ \\
\hline$\Delta \mathrm{LH}$ & $3.64^{\star *}(0.05)$ & $0.07(0.92)$ & $0.42(0.5)$ & $0.07(0.77)$ & $0.34(0.00)$ & - & $0.10^{*}[3.74]$ \\
\hline
\end{tabular}

GDP Model, AR (1)=86.84 ((0.9)), JB=1348 ((0.01)), FDI Model, AR (1)=86.84 ((0.0)) JB=1437 ((0.05)), EXP Model, AR (1)=86.84 ((0.5)), JB=1519 ((0.02)), AID Model, AR $(1)=86.84((0.04)), \mathrm{JB}=127.44((0.02))$, LPOP Model, AR $(1)=86.84((0.03)), \mathrm{JB}=127.44((0.1))$, LDI Model, AR (1)=86.84 ((0.01)), JB=839.30 ((0.49)) 


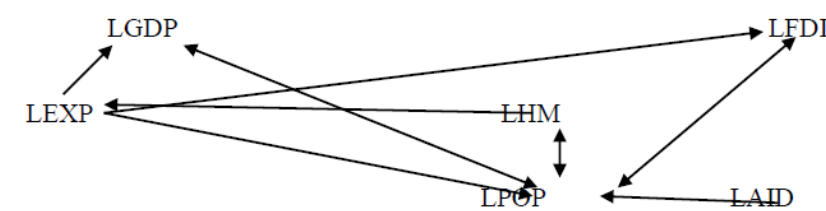

Figure 1: Summary of the results from of Table 6

foreign donors and multilateral aid agencies to ensure that, Tanzania as well as African countries are progressing economically. These initiatives are intended to alleviate the countries from poverty, budget deficits and helping them achieve macroeconomic stability. Tanzania as one of Sub Saharan African Country is heavily dependent on foreign aid for long time since 1970s.

It is argued that, Tanzania is one among the top ten ODA recipients in terms of USD millions. However, despite the fact that several bilateral and multilateral aid donors to increase foreign aid in Tanzania, the economic growth rate of these countries is apparently low compared to other developing countries. Poor level of technology, low income per capita and poverty levels still persist in Tanzania. According to the World Bank (2006) Tanzania are still categorized as heavily indebted poor countries (HIPC). In that sense, the appropriate economic policies are highly needed to ensure that, these countries have appropriate policies to develop themselves from economic backwardness. Thus it is worthwhile to investigate the impact of foreign aid, whether it can reduce the problem of severe poverty and economic development.

Generally, there are no conclusive results from the empirical literatures on the relationship between foreign aid and economic growth. Specifically, for the case of foreign aid some studies founds that, foreign aid has a direct and positive impact to the economic growth. However, some studies empirically proved that, good economic environment is main prerequisites to ensure the positive impact of foreign aid to the economic growth. Furthermore, several studies have shown that, foreign aid has negative impact on the economic growth

Major weakness from the previous literatures of 1970s to 1980 analyzed the relationship between foreign aid and economic growth in the Harrod-domar and the two gap theories. Besides, most of the previous literatures were used cross section or panel data methods. Thus in contrast with the previous literatures, our study intends to further investigate the impact of foreign aid to the Tanzania. The study uses the appropriate methods developed by Stock and Watson (1993) which is dynamic ordinary least squares (DOLS). Since we are also interested to find the short run relationship between foreign aid and economic growth we use Vector error Correction Model

The results from DOLS show that, foreign aid; export, human capital and labor force (proxied by population) was only significant factors that affecting the GDP per capital. Human capital has highest impact (1.7\%) followed by labor force (1.11\%), export (0.26\%) and least one is foreign aid $(-0.12 \%)$. Since our study concentrate on foreign aid, we found that, in long run foreign aid has negative impact to the economic growth. The negative impact of foreign aid to economic growth has several implications. The increase in foreign aid can distorts domestic saving, increase domestic consumptions and discourages tax revenue in Tanzania. Furthermore, foreign aid is given according to the political needs and not economic needs. This creates major economic problems and results to support unproductive projects which results to negative impact to economic growth.
Furthermore, for the short run impact (Causality) that were shown by Vector Error Correction Model (VECM) only two error correction terms of FDI and populations (labor force) responds to any deviations from equilibrium relationship. Foreign aid, economic growth, export and human capital, population's growth does no responds to any deviations from equilibrium. The main result here is that, foreign aid granger causes FDI inflows in short run and not otherwise at ten percent level of significance. Unfortunately, this impact is not transmitted to economic growth which implies major policy problems.

Generally, from the results we argue that, Tanzania has to reconsider again the type of foreign aid that it receives, if they are still needed to support their economic activities. Furthermore, the government has to ensure that, foreign aid is channeled to more productive sectors such as industry development, infrastructures and human capital development. The government has to control the corruptions and funds embezzlements and ensure good management of the resources. Future studies can further investigate the impact of foreign aid after decomposing into different branches such as humanitarian aid, social infrastructure aid, and production aid instead of looking the impact of total aid to the economic growth. We failed to do this analysis due to the failure of enough time series data especially in Tanzania.

\section{References}

1. MDP Reports. (2013) Foreign aid in Tanzania.

2. Malik G (2008) Foreign aid and economic growth: A co integration Analysis of the six poorest African countries. Economic Analysis and Policy 38: 251-260.

3. Njoupougnigni $\mathrm{M}, \mathrm{Ndambendia} \mathrm{H}$ (2011) Foreign aid, foreign direct investment and economic growth in Sub Saharan African countries: Evidence from pooled Mean Group Estimator (PMG). International Journal of Economics and Finance 2: $39-45$.

4. Rotarou E, Ueta K (2009) Foreign aid and economic development: Tanzania's Experience with ODA. Kyoto Economic Review 78: 157-189.

5. Chenery HB, Strout AM (1966) Foreign assistance and economic development American EconomicReview 56: 679-733.

6. Bacha EL (1990) A three gap models of foreign transfers and the GDP growth rate in developing countries. Journal of Development Economics 32: 279-296.

7. Taylor $L$ (1990) Foreign resource flows and developing country growth: $A$ threegap analysis. Research for Action pp: 55-90.

8. Griffin K (1970) Foreign capital, domestic savings and economic development Oxford Bulletin of Economics and Statistics 32: 99-112.

9. Griffin K, Enos J (1970) Foreign assistance, objectives and consequences Economic Development and Cultural Change 18: 313-337.

10. Turnovsky SJ (2008) The role of factor substitution in the theory of economic growth and income distribution: Two examples. Journal of Macroeconomics, 30: 604-629.

11. Pallage S, Robe MA (2001) Foreign aid and the business cycles. Review of International Economics 9: 641-672.

12. Burnside C, Dollar D (2000) Aid, policies and growth. American Economic Review 90: 847-868.

13. Nyoni TJ (1998) Foreign aid and Economic and Economic performance in Tanzania. World Developement, 26: 1235-1240.

14. Easterly W (2003) Can foreign aid buy growth? Journal of Economic Perspective 17: 23-48

15. Choudhary M, Das A (2011) Aid growth nexus-South East Asian: Evidence from time series and Panel co integration. Research in Applied Economics 3 . 1-19.

16. Sakyi D (2011)Trade openness, foreign aid and economic growth in postliberation Ghana: An application of ARDL bound test. Journal of Economics and International Finance 3: 146-156.

17. Bjenrg C, Bjornskov C, Holm A (2011) Growth, debts burden and alleviating 
Citation: Albiman MM (2016) What are the Impact of Foreign Aid to the Economic Growth? Time Series Analysis with New Evidence from Tanzania. Bus Eco J 7: 237. doi:10.4172/2151-6219.1000237

effects of foreign aid in least developed countries. European Journal of Political Economy 27: 143-153.

18. Kargbo MP (2012) Impact of foreign aid on economic growth in Sierra Leone. Working paper.

19. Nelson CR, Plosser CR (1982) Trends and random walks in macroeconomic time series: Some evidence and implications. Journal of Monetary Economics 10: $139-162$

20. Solow RM (1956) A contribution to the theory of economic growth. Quarterly Journal of Economics 70: 65-94.

21. Solow RM (1957) Technical change and the aggregate productions. Reviews of Economic and Statistics 39: 312-320.

22. Romer PM (1986) Increasing return and long run growth. Journal of political Economy 94: 1002-1037.

23. Lucas RE (1988) On the mechanisms of economic development. Journal of Monetary Economics 22: 3-42.

24. Akinlo AE (2004) Foreign direct investment and growth in Nigeria: An empirical investigation. Journal of Policy Modeling 26: 627-639.
25. Stock JH, Watson MW (1993) A simple estimator of co integrating vectors in higher order integrated systems. Econometrica 61: 783-820.

26. Singh T (2010) Does domestic saving cause economic growth?. Time-series evidence from India. Journal of Policy Modeling 32: 231-253.

27. Majeed H (2007) Estimating Long run elasticity of Jordanian import demand functions. Applications of dynamic ordinary least square (DOLS). Applied Econometrics and international development 7: 171-182.

28. Masih R, Masih AM (1996) Stock-Watson dynamic OLS (DOLS) and errorcorrection modeling approaches to estimating long-and short-run elasticities in a demand function: New evidence and methodological implications from an application to the demand for coal in mainland China. Energy Economics 18: 315-334.

29. Masih, AMM, Masih R (1999) Are Asian stock market fluctuations due mainly to intra-regional contagion effects? Evidence based on Asian emerging stock markets. Pacific-Basin Finance Journal 7: 251-282.

30. Mosley P (1980) Aid, savings and growth revisited. Oxford Bulletin of Economics and Statistics volume 42: 79-95. 